2018 Global Marketing Conference at Tokyo Proceedings: 1235-1238 (July 2018) https://doi.org/10.15444/GMC2018.10.05.01

\title{
ARE YOU IN(GAGED)? \\ THE IMPORTANCE OF ENGAGEMENT AND EXPERIENCE ON EMPLOYEES AND ORGANIZATIONS' SUCCESS
}

Liliana Rodrigues da Costa, Instituto Universitário de Lisboa (ISCTE-IUL) and Business research Unit (BRU/UNIDE), Portugal ${ }^{1}$

Sandra Maria Correia Loureiro, Instituto Universitário de Lisboa (ISCTE-IUL) and Business research Unit (BRU/UNIDE), Portugal ${ }^{2}$

\begin{abstract}
Introduction

This study intends to analyse the impact of the engagement and employee experience towards the employee and employer success. The results demonstrate that organisations are conscious of the importance of retain and create happiness at work and are starting to create an internal experience for their workforce. They want to have employees engaged and retain talent. When employees are more committed to be happier at work they tend to take part of the ownership of their organisations. Employers and employees are more focused on people and the value that they can add to every single product and/or service they design, create and deliver. All this investment on internal world is feeding a better consumer experience as the quality standards are getting higher.
\end{abstract}

\section{Theoretical development}

The main goal is to evidence how the engagement is attaining more importance on both sides: employee and employer. In the past years, a growing number of studies and are giving more importance to the human side on organisations (e.g., Sinek, 2009; Nayar, 2010; Medeiros 2017). From the transactional economy, organizations are walking to an emotional, experience economy. In the customer-centric dynamics, organisations are taken employees first because these, once deep involved with the mission and goals of the organization, will be more devoted to customers. People "who love going to work are more productive and more creative. They go home happier and have happier families. They treat their colleagues and customers better. Inspired employees make stronger economies." (Sinek, 2009, p.14) Without happy and empowered employees, the service will never achieve the best and higher levels to then be delivered to the customers. Company "can (should) focus on its value creators - the frontline employees. (...) in his or her knowledge, creativity commitment to tasks, and capacity to collaborate. In fact, (...) "the true value is created in the interface between the customer and the employee. (...) When a company puts its employees first, the customer actually does ultimately come first and gains the greatest benefit." (Nayar, 2010, p.7). Internal engagement is crucial to companies' reputation, to brand/service perception and ultimately for the business survival and successful future: "Employees who are dispositionally self-efficacious and proactive are likely to use their initiative, engage in proactive service performance,

\footnotetext{
${ }^{1}$ liliana.r.costa@gmail.com

2 sandramloureiro@netcabo.pt
} 
take charge to bring about change, proactively solve problems and implement ideas." (Patterson et al., 2009).

\section{Research design}

According to the authors of the model applied, "we define engagement as the attitude, behaviour, the level of connectedness among customers, between customers and employees and of customers and employees with the firm." (Kumar and Pansari, 2016, p. 498). This was the starting point for our interviews and our study. To complete this exploratory study, we've decided to follow a qualitative research by creating a script and interviewed 4 people in 10 organisations based in Lisbon. "Qualitative research starts from and returns to words, talk, and texts as meaningful representations of concepts." (Pratt, 2009, p.856). The original script was written in English, then translated to Portuguese to be applied on the organisations. Each interview was fully transcript in Portuguese and the main findings and relevant content were enlightened in English to produce this paper. On each organisation, four employees were chosen: two women and two men from different departments and positions - board management, executive leadership, line managers and individual contributors. All interviewed people have Portuguese nationality and have a labour contract with their employer organisation. None outsourced employees have been selected to this study. All employees have between 25 and 50 years old. Interviews were done individually on the headquarters of each organisation. Interviews took between 45 and 60 minutes each. All conversations have been recorded with the individual's authorisation. The note of confidentiality was explained and applied to all of them. The interviews followed the same script: three main blocks on a semi-structure script. Participants were asked to think about engagement and experience and share their thoughts and examples. Different organisations were chosen: multinational companies, agencies, national companies, private funds. The diversity of the organisations was accepted and taken as an added value to our work. To convert all audio into text, we've applied the google audio tool and a Huawei phone app that can transform audio into text. A final check was done in order to verify all sentences and avoid mishaps. After all transcription, a content analysis has been done and the most relevant facts, insights and details have been listed. The content analysis was done using the MAXQDA software.

\section{Results and conclusions}

The main goal of this exploratory study was to determine how engagement and experience are taking such an important role on employees and employers success. In order to be happier at work, employees are more committed and accountable. In the same equation, and to retain more talent, organisations are more focused on employees and how to design and delivery to them a better internal experience. The main finding confirm that happier and recognised employees work better, work more and have the ownership of the organisations they work for. Once people are happy and have good work conditions - financial, physic and technological - they will go further and beyond to deliver their tasks and when needed they will internally cooperate with their teammates or with other departments. To promote this good environment and to keep workforce with them, employers are changing the future of work, nevertheless a few organisations are not applying this or taking these questions as a priority. According to the content analysis of all interviews below a few findings that we would like to highlight: 
1) Most of the interviewees say they like their jobs and they are happy at work. They feel that they are part of something: family, team, organisation, culture.

2) The feeling of belonging was mentioned multiple times - the emotional link and the human aspect of being accepted and valuable inside the organisation.

3) All interviewed people, despite the job and the position they have, spoke about the power of recognition and the importance of this aspect to retain talent.

4) All interviewed people raised the importance of happiness at work, the wellbeing variable and the crucial aspect of work/life balance.

5) All interviewed employees agreed that their organisations value more the individual, their soft skills, than the job position and the tasks that there are committed and designated to do.

6) From the point of view of organisations, as leaders and builders of a strategy, we could note that only a few are planning and designing a structured employee experience. Nevertheless, all companies have a list of benefits and create events to get together their employees and promote a better life for them. Following a more structured or more informal way, all interviewed organisations implement a list of actions to create a good work environment: flexibility on the work hours, the possibility to work from home, the team/company dinners and parties; the physical structure with infrastructures to have lunch or to have a break; the empowerment of the employees by asking them to be part of the decisions.

7) Only a few of the interviewed claim that their organisations are promoting situations of work mobility and career progression. Most of the people explained that is difficult to grow or to move from departments.

8) Both, organisations and employees, understand that the salary is not an imperative condition to work or to retain people. Employees value more other work conditions and benefits.

The fact is that different and heterogeneous organisations understand and reveal concern in taking care of their people and on the importance of retain their employees. Strategies, or more simple activities, are taking place. All of 40 employees, aside their gender, ages, under all circumstances and positions, want the same: recognition, to be happy and to balance, the best way possible, their work and their life. People want to be treated as people, as an exclusive human being as each of one of human beings are: a unique person and to be recognise whenever they do an extra effort. And this is the part of the key for the success of employers and employees (see figure 1).

Figure 1: Engagement and success: employees and employees dynamic

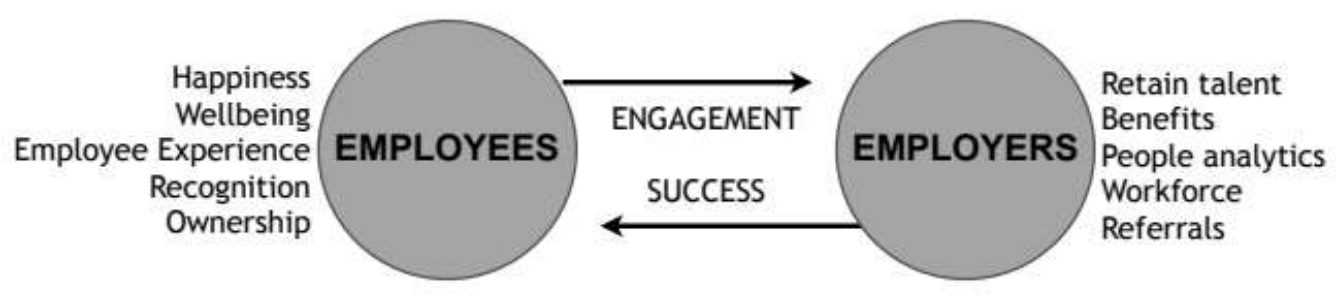

Source: authors' elaboration

Keywords: engagement, experience, employee, recognition, happy

\section{References}


Kumar, V. \& Pansari, A. (2016). Competitive Advantage Through Engagement", Journal of Marketing Research, 53(4), 497-514.

Medeiros, E. (2017). Welcome to the Experience Economy, Lisbon: Uirtus Academy: Lisbon.

Nayar, V. (2000). Employees First, Customer Second, Boston: Harvard Business Press

Patterson, F., Kerrin, M. \& Roissard, G. (2009). Characteristics \& behaviours of Innovative People in Organisations, London: Literature Review Prepared for the NESTA Policy \& Research. Unit, NESTA.

Pratt, M. G. (2009). From the editors, For the lack of a boilerplate. Tips on writing up (and reviewing) qualitative research. Academy of Management Journal, 52, 856-862.

Sinek, Simon, Start with Why, Portfolio Penguin, 2009. 